\title{
Risiko Malnutrisi terhadap Jumlah CD4+ Orang dengan HIV/AIDS yang Menjalani Terapi Antiretroviral di Mimika
}

\section{Risk of Malnutrition on CD4+ Level of People Living with HIV/AIDS Receiving Antiretroviral Therapy in Mimika}

\author{
Setyo Adiningsih, Mirna Widiyanti \\ Laboratorium Imunologi Balai Penelitian dan Pengembangan Biomedis Papua
}

\begin{abstract}
ABSTRAK
Hubungan status gizi dengan Cluster of Differentiation $4\left(\mathrm{CD}^{+}\right)$pada Orang Dengan HIV/AIDS (ODHA) yang menjalani terapi antiretroviral (ARV) di Papua belum banyak diketahui. Penelitian bertujuan menganalisis hubungan status gizi terhadap jumlah $\mathrm{CD}^{+}$subjek penelitian. Parameter status gizi yang digunakan yaitu Indeks Massa Tubuh (IMT) dan anemia. Jenis penelitian adalah observasional deskriptif dengan desain cross-sectional. Inklusi yaitu pasien laki-laki dan perempuan sedang terapi ARV minimal 6 bulan, memiliki data CD4 dan rekam medis lengkap. Subjek penelitian yaitu 64 pasien HIV/AIDS yang menjalani terapi ARV di Rumah Sakit Mitra Masyarakat (RSMM) Mimika Papua bulan Januari sampai Oktober 2015, telah menyetujui inform consent dan memenuhi kriteria inklusi. Data dianalisis menggunakan statistik Fisher's Exact test dan Odds Ratio (OR). Mayoritas subjek penelitian adalah perempuan sebanyak 76,6\%, kisaran umur 1535 tahun sebanyak 60,9\%, IMT >18,5 sebanyak 85,9\%, kadar hemoglobin $(\mathrm{Hb})<13 \mathrm{~g} / \mathrm{dL}$ sebanyak $73,4 \%$, dan lama terapi $\leq 60$ bulan sebanyak $75 \%$. Hasil Fisher's Exact test dan $O R$, ada hubungan signifikan IMT terhadap jumlah $\mathrm{CD}^{+}$dengan nilai $\mathrm{p}<0,05=0,006$ dan $\mathrm{OR}=13,867$ serta $95 \%$ interval konvidensi $(\mathrm{Cl})=2,396-80,266$. Hal ini menunjukkan subjek penelitian dengan IMT $\leq 18,5$ atau malnutrisi berisiko 13,867 kali untuk memiliki jumlah $\mathrm{CD}^{+} \leq 200$ sel/ul dibandingkan subjek dengan IMT>18,5. Variabel jenis kelamin, umur, kadar Hb, dan lama terapi ARV tidak berhubungan signifikan dengan jumlah CD4 . IMT kurus (malnutrisi) berhubungan signifikan dengan jumlah $\mathrm{CD}^{+}$rendah yaitu $\leq 200 \mathrm{sel} / \mathrm{ul}$. Jumlah $\mathrm{CD4} 4^{+} \leq 200 \mathrm{sel} / \mathrm{ul}$ berisiko mempercepat status HIV menjadi stadium 4 atau sakit berat yang mengarah kepada AIDS.
\end{abstract}

Kata Kunci: Antiretroviral, CD4 ${ }^{+}$, HIV, malnutrisi, Mimika

\begin{abstract}
The relation of nutritional status with Cluster of Differentiation $4\left(C D 4^{+}\right)$in People Living with HIV/AIDS (PLWHA) receiving antiretroviral (ARV) therapy in Papua has not been widely known. This study aimed to analyze the correlation between nutritional status and $C D 4^{+}$cell count of PLWHA receiving ARV therapy. Parameters of nutritional status used were Body Mass Index (BMI) and anemia status. This was a cross-sectional descriptive study. The inclusions were male and female patients receiving $A R V$ for at least 6 months and having $C D 4^{+}$data and complete medical record. Respondents were 64 HIV/AIDS patients undergoing ARV therapy at Mitra Masyarakat Hospital in Mimika Papua from January to October 2015, approved informed consent, and met the inclusion criteria. Data were analyzed using Fisher's Exact test and Odds Ratio (OR). Majority of respondents were women (76,6\%), ranging 15-35 years old (60,9\%), had IMT>18,5 (85,9\%), had Hemoglobin $(\mathrm{Hb})<13 \mathrm{~g} / \mathrm{dL}(73,4 \%)$, and received ARV therapy $\leq 60$ months (75\%). Fisher's Exact test and OR results showed a statistically significant relationship of $B M I$ on $C D 4^{+}$cell count with $p<0,05=0,006,0 R=13,867$, and $95 \%$ confidence interval $(C I)=2,396-80,266$. It shows that respondents with $B M I \leq 18,5$ or malnutrition had 13.867 times risk to have $C D 4^{+}$ count $\leq 200 \mathrm{cells} / \mathrm{ul}$ compared to respondents with IMT>18,5. Variables of sex, age, Hb level, and ARV therapy duration were not significantly correlated with CD4 $4^{+}$cell count. Low IMT or malnutrition was significantly associated with low CD4 ${ }^{+}$ cell count of $\leq 200 \mathrm{cells} / \mathrm{ul}$. CD4 ${ }^{+}$cell counts $\leq 200 \mathrm{cell}$ / /ul have the risk of accelerating HIV status to stage 4 or severe illness leading to AIDS.
\end{abstract}

Keywords: Antiretroviral, $C D 4^{+}$, HIV, malnutrition, Mimika

Korespondensi: Setyo Adiningsih. Laboratorium Imunologi Balai Penelitian dan Pengembangan Biomedis Papua, Jl. Kesehatan Nomor 10 Dok II Jayapura 99112, KotakPos 1427. Tel(0967) 534389/082248568412 Email: tyoadining@gmail.com 


\section{PENDAHULUAN}

Human Immunodeficiency Virus (HIV) adalah virus yang menyerang sistem imunitas. HIV dapat berkembang menjadi Acquired Immune Deficiency Syndrome (AIDS) yaitu sindrom penyakit yang muncul karena melemahnya sistem kekebalan tubuh. Fase AIDS dapat memicu mortalitas Orang Dengan HIV/AIDS (ODHA) karena infeksi berbagai penyakit (1).

Kasus infeksi HIV/AIDS masih menjadi permasalahan kesehatan di Indonesia, khususnya di Papua. Menurut laporan Direktorat Jenderal Pencegahan dan Pengendalian Penyakit Kementerian Kesehatan sampai triwulan I tahun 2017 tentang situasi perkembangan HIV/AIDS di Indonesia menyatakan Provinsi Papua menduduki urutan ketiga tertinggi kasus HIV setelah Provinsi DKI Jakarta dan Jawa Timur, dengan jumlah kasus HIV sebanyak 25.586 orang. Selain itu, Provinsi Papua juga menduduki posisi kedua tertinggi kasus AIDS setelah Provinsi Jawa Timur dengan jumlah kasus AIDS sebanyak $13.398(2)$.

Pengobatan HIV saat ini menggunakan obat antiretroviral (ARV) yang berfungsi untuk menekan jumlah virus dalam tubuh ODHA. Terapi ARV dengan kepatuhan baik berdasarkan studi berbagai penelitian dapat membantu ODHA untuk memperlambat progresivitas HIV menjadi AIDS, sehingga ODHA dapat memiliki kualitas hidup lebih baik dan menurunkan jumlah kematian karena $\operatorname{AIDS}(3,4)$. Keberhasilan terapi ARV dapat ditandai dengan peningkatan jumlah $\mathrm{CD} 4^{+}$, jumlah virus sedikit atau tidak terdeteksi di dalam darah.

Cluster of Differentiation $4\left(\mathrm{CD}^{+}\right)$adalah molekul protein yang berada di permukaan sel T-Limfosit. CD4 ${ }^{+}$berperan sebagai reseptor HIV yang membantu virus masuk dalam sel. Virus dalam sel T-Limfosit kemudian memperbanyak materi genetik dan partikel virus, yang akhirnya merusak sel T-Limfosit dengan memproduksi banyak virus HIV baru dalam tubuh (5). CD4+ juga digunakan sebagai penanda status imunologis ODHA dan keberhasilan terapi antiretroviral, beserta dengan status virologis ODHA. Analisis jumlah $\mathrm{CD}^{+}$banyak digunakan karena biaya lebih terjangkau dibandingkan analisis jumlah virus HIV dalam tubuh (6).

Status gizi ODHA selama terapi perlu mendapatkan perhatian. Ada hubungan antara status gizi dengan HIV/AIDS $(7,8)$. Malnutrisi pada ODHA disebabkan oleh kombinasi dari efek langsung HIV, infeksi oportunistik, berkurangnya asupan nutrisi, gangguan penyerapan nutrisi, dan peningkatan energi tubuh untuk memperbaiki imunitas. Malnutrisi merupakan faktor risiko bagi ODHA untuk terkena infeksi oportunistik dan stadium AIDS $(9,10)$.

Status gizi pada ODHA dapat dievaluasi dari Indeks Massa Tubuh (IMT) dan status anemia yang dapat dilihat dari kadar Hemoglobin ( $\mathrm{Hb}$ ). Pembagian IMT berdasarkan definisi dari World Health Organization (WHO) yaitu kurus, normal, kelebihan berat badan, dan obesitas. Kategori kurus yaitu IMT<18,50; normal yaitu IMT 18,5024,99; kelebihan berat badan yaitu IMT $\geq 25$; obesitas yaitu IMT $\geq 30$ (11). Berdasarkan kriteria WHO, anemia adalah kondisi fisiologis darah dengan jumlah hemoglobin $<12$ $\mathrm{g} / \mathrm{dL}$ pada perempuan dan hemoglobin $<13 \mathrm{~g} / \mathrm{dL}$ pada laki-laki (12).

Infeksi HIV/AIDS menjadi permasalahan kesehatan di Papua. Angka kasus AIDS di Papua diketahui tertinggi di
Indonesia yaitu sebesar 416,91 per 100.000 jumlah penduduk (2). AIDS merupakan kondisi parah dari infeksi HIV. Di Papua, Kabupaten Mimika merupakan kabupaten penyumbang angka kasus infeksi HIV/AIDS tertinggi kedua (13), dimana tingkat kepatuhan ODHA minum ARV di Mimika masih rendah yaitu dibawah $80 \%$ (14). Namun, informasi tentang status gizi ODHA yang menjalani terapi ARV di Mimika belum banyak diketahui. Informasi tentang status gizi ODHA dapat digunakan untuk evaluasi dan intervensi dalam mendukung keberhasilan terapi ARV. Studi ini dilakukan untuk mengetahui hubungan status gizi dengan jumlah CD4+ pada ODHA di Rumah Sakit Mitra Masyarakat (RSMM) Mimika tahun 2015. Informasi tentang status gizi yang diperoleh dari penelitian diharapkan dapat bermanfaat dalam mendukung program terapi ARV ODHA di Mimika, Papua.

\section{METODE}

Pengambilan sampel dilakukan di Rumah Sakit Mitra Masyarakat (RSMM) Mimika, Papua mulai bulan Januari hingga Oktober 2015. Responden yang terlibat adalah ODHA yang menjalani terapi ARV. Jumlah responden yang berhasil dikumpulkan sebanyak 90 responden. Dari 90 responden tersebut, hanya 64 responden yang dapat dianalisis datanya. Penelitian menggunakan rancangan penelitian cross-sectional. Inklusi penelitian adalah responden laki-laki dan perempuan positif HIV/AIDS, menjalani terapi ARV lebih dari 6 bulan, memiliki data CD $4^{+}$ dan riwayat rekam medis. Penelitian ini telah mendapatkan persetujuan etik dari Komisi Etik Penelitian Kesehatan Badan Litbang Kesehatan Kementerian Kesehatan RI, Nomor: LB.02.01/5.2/KE.156/2015.

Data demografi dan data klinis diperoleh dari rekam medis responden. Data mentah tersebut merupakan data dari penelitian HIV Balai Litbang Biomedis Papua tahun 2015 (15). Data demografi berupa jenis kelamin dan usia, sedangkan data klinis yaitu IMT, kadar hemoglobin dan lama terapi ARV. Penghitungan jumlah $\mathrm{CD}^{+}$dilakukan dengan cara mengambil darah responden melalui pembuluh darah perifer di ujung jari menggunakan Alere Pima $^{\text {TM }}$ CD4 cartridge (OUS). Catridge berisi darah kemudian dimasukkan dalam alat $\mathrm{CD}^{+}$Alere $\mathrm{Pima}^{\mathrm{TM}} \mathrm{CD}^{+}$ analyser, dan ditunggu selama \pm 20 menit untuk penghitungan. Kadar hemoglobin responden pada rekam medis diperoleh dari sampel darah menggunakan Automated Hematology Analyzer SYSMEX XP 100 (PT Sysmex Indonesia). Nilai IMT dihitung menggunakan data hasil pengukuran berat badan dan tinggi badan responden. Penghitungan IMT menggunakan rumus: IMT=berat badan $(\mathrm{kg}) /$ tinggi badan $(\mathrm{m})^{2}$. Status gizi ODHA dievaluasi berdasarkan IMT dan status anemia yang dapat dilihat dari kadar hemoglobin (Hb). Pembagian kisaran IMT yang digunakan dalam analisis statistik pada penelitian ini yaitu IMT $\leq 18,50$ dan IMT $>18,50$. Pembagian kisaran kadar $\mathrm{Hb}$ yang digunakan yaitu $\mathrm{Hb}<13 \mathrm{~g} / \mathrm{dL}$ dan $\mathrm{Hb} \geq 13 \mathrm{~g} / \mathrm{dL}$. Sedangkan untuk jumlah $\mathrm{CD}^{+}$digunakan pembagian $\mathrm{CD}^{+} \leq 200 \mathrm{sel} / \mu \mathrm{l}$ dan $\mathrm{CD}^{+}>200 \mathrm{sel} / \mu \mathrm{l}$.

Analisis data statistik menggunakan aplikasi IBM SPSS Statistic versi 20. Analisis univariat digunakan untuk mengetahui distribusi variabel jenis kelamin, umur, IMT, kadar hemoglobin, dan lama terapi. Analisis lanjutan chikuadrat dilakukan menggunakan uji Fisher's exact dan Odds Ratio (OR) untuk mengetahui hubungan variabel jenis kelamin, umur, IMT, kadar hemoglobin, dan lama 
terapi dengan jumlah $\mathrm{CD}_{4}^{+}$pada nilai $p<0,05$ dan interval konfidensi 95\%. Digunakan uji Fisher exact karena jumlah sampel yang diperoleh memenuhi untuk tabulasi $2 \times 2$, selain itu digunakan analisis OR untuk mengetahui risiko dari variabel yang diperiksa terhadap jumlah $\mathrm{CD}^{+}$.

\section{HASIL}

Gambaran karakteristik subjek penelitian menunjukkan mayoritas subjek penelitian adalah perempuan sebanyak $49(76,6 \%)$ dan kisaran umur 15-35 tahun sebanyak 39 $(60,9 \%)$. Subjek penelitian dengan Indeks Massa Tubuh $>18,5$ sebanyak $55(85,9)$ dan kadar $\mathrm{Hb}<13 \mathrm{~g} / \mathrm{dL}$ sebanyak $47(73,4 \%)$ serta lama terapi $\leq 60$ bulan sebanyak 48 (75\%) (Tabel 1).

Tabel 1. Karakteristik subjek penelitian yang menjalani terapi arv di rsmm mimika tahun 2015

\begin{tabular}{llcc}
\hline \multicolumn{2}{c}{ Variabel } & Frekuensi (f) & Proporsi (\%) \\
\hline Jenis kelamin & Laki-laki & 15 & 23,4 \\
& Perempuan & 49 & 76,6 \\
& Total & 64 & 100 \\
Umur & $15-35$ tahun & 39 & 60,9 \\
& $>35$ tahun & 25 & 39,1 \\
Indeks Massa Tubuh & Total & 64 & 100 \\
& $\leq 18,5$ & 9 & 14,1 \\
Hemoglobin (Hb) & $>18,5$ & 55 & 85,9 \\
& Total & 64 & 100 \\
& $<13$ g/dL & 47 & 73,4 \\
& $\geq 13$ g/dL & 17 & 26,6 \\
Lama Terapi & Total & 64 & 100 \\
& $\leq 60$ bulan & 48 & 75 \\
& $>60$ bulan & 16 & 25 \\
& Total & 64 & 100 \\
\hline
\end{tabular}

Hasil analisis statistik hubungan variabel karakteristik subjek penelitian dengan jumlah $\mathrm{CD}^{+}$dapat dilihat pada Tabel 2. Berdasarkan hasil uji Fisher's exact, terdapat hubungan bermakna atau signifikan secara statistik antara Indeks Massa Tubuh dengan jumlah $\mathrm{CD}^{+}$dengan nilai $\mathrm{p}=0,006$ dan Odd Ratio (OR)=13,867 pada 95\% interval konfidensi $(\mathrm{Cl})=2,396-80,266$. Hal ini menunjukkan bahwa subjek penelitian yang memiliki Indeks Massa Tubuh $\leq 18,5$ atau malnutrisi akan berisiko 13,867 kali untuk memiliki jumlah $\mathrm{CD}^{+} \leq 200 \mathrm{sel} / \mathrm{ul}$ dibandingkan subjek penelitian yang memiliki Indeks Massa Tubuh >18,5. Variabel jenis kelamin, umur, kadar hemoglobin, dan lama terapi ARV tidak berhubungan signifikan dengan jumlah $\mathrm{CD}^{+}$.

\section{DISKUSI}

Mayoritas subjek dalam penelitian ini adalah perempuan sebanyak 76,6\%. Kasus HIV/AIDS per 31 Desember 2016 yang dilaporkan Dinas Kesehatan Provinsi Papua menunjukkan paling banyak adalah perempuan sebanyak $50,7 \%$ (13). Publikasi hasil penelitian oleh Jamil di Banda Aceh tahun 2014, mayoritas penderita HIV/AIDS adalah laki-laki yaitu sebanyak 64,4\% (16). Penelitian Saktina di Rumah Sakit Umum Pusat Sanglah 2017 menunjukkan mayoritas adalah laki-laki sebanyak $67,7 \%$ (17). Penelitian Widiyanti menunjukkan jumlah kasus HIV yang menginfeksi laki-laki dan perempuan di Rumah Sakit Yowari adalah sebanding (50\%) (18). Menurut laporan Dirjen Pencegahan dan Pengendalian Penyakit Kementerian Kesehatan RI sampai triwulan I tahun 2017 menunjukkan laki-laki paling banyak menderita HIV yaitu sebanyak $66,2 \%$ dan AIDS sebanyak $70,9 \%$. Pola infeksi kasus HIV/AIDS tahun sebelumnya banyak ditemukan pada subjek laki-laki namun kasus yang ditemukan pada perempuan cenderung semakin banyak dan mendekati jumlah kasus pada laki-laki (2). Secara umum, laki-laki masih mendominasi penderita HIV/AIDS di Indonesia. Menurut data dari UNAIDS sampai tahun 2015 secara global dari total orang dewasa yang baru terinfeksi HIV diperkirakan sebanyak 53\% di antaranya adalah laki-laki, sedangkan untuk kasus secara keseluruhan pada orang dewasa jumlahnya sebanding antara laki-laki dan perempuan (19). Jumlah perempuan terinfeksi HIV semakin banyak karena perempuan lebih rentan secara biologis dan sosial untuk tertular HIV dari pasangannya. Namun, secara nasional dan global, laki-laki masih berisiko tinggi untuk terinfeksi HIV dibandingkan perempuan.

HIV/AIDS menginfeksi kelompok usia produktif. Mayoritas penderita HIV/AIDS dalam penelitian ini berumur 15-35 tahun. Menurut laporan (pusdatin) Kementerian Kesehatan RI, infeksi HIV/AIDS cenderung meningkat dan terbanyak ditemukan pada kelompok umur 25-49 tahun

Tabel 2. Hubungan cd4+ dengan variabel karakteristik subjek penelitian yang menjalani terapi arv di rsmm mimika tahun 2015

\begin{tabular}{|c|c|c|c|c|c|c|}
\hline \multirow{2}{*}{\multicolumn{2}{|c|}{ Variabel }} & \multicolumn{2}{|c|}{ Jumlah CD4 $^{+}$} & \multirow[b]{2}{*}{ Total } & \multirow[b]{2}{*}{ OR $(95 \% \mathrm{Cl})$} & \multirow[b]{2}{*}{ nilai $p$} \\
\hline & & $\begin{array}{c}\mathrm{CD4}^{+} \leq 200 \\
\text { sel/ul }\end{array}$ & $\begin{array}{c}\mathrm{CD4}^{+}>\mathbf{2 0 0} \\
\text { sel/ul }\end{array}$ & & & \\
\hline \multirow[t]{3}{*}{ Jenis kelamin } & Laki-laki & 1 & 14 & 49 & $1,953(0,216-17,652)$ & 1,000 \\
\hline & Perempuan & 6 & 43 & 15 & & \\
\hline & Total & 7 & 57 & 64 & & \\
\hline \multirow[t]{3}{*}{ Umur } & 15-35 tahun & 4 & 35 & 39 & $0,838(0,171-4,106)$ & 1,000 \\
\hline & $>35$ tahun & 3 & 22 & 25 & & \\
\hline & Total & 7 & 57 & 64 & & \\
\hline \multirow[t]{3}{*}{ Indeks Massa Tubuh } & $\leq 18,5$ & 4 & 5 & 9 & $13,867(2,396-80,266)$ & $0,006 *$ \\
\hline & $>18,5$ & 3 & 52 & 55 & & \\
\hline & Total & 7 & 57 & 64 & & \\
\hline \multirow[t]{3}{*}{ Hemoglobin $(\mathrm{Hb})$} & $<13 \mathrm{~g} / \mathrm{dL}$ & 6 & 41 & 47 & $2,341(0,261-21,014)$ & 0,664 \\
\hline & $\geq 13 \mathrm{~g} / \mathrm{dL}$ & 1 & 16 & 17 & & \\
\hline & Total & 7 & 57 & 64 & & \\
\hline \multirow[t]{3}{*}{ Lama Terapi } & $\leq 60$ bulan & 6 & 42 & 48 & $2,143(0,238-19,292)$ & 0,669 \\
\hline & $>60$ bulan & 1 & 15 & 16 & & \\
\hline & Total & 7 & 57 & 64 & & \\
\hline
\end{tabular}


dan 20-24 tahun. Penelitian Saktina tentang karakteristik penderita AIDS di Rumah Sakit Umum Pusat Sanglah menunjukkan mayoritas penderita berusia 30 sampai 39 tahun (17), demikian juga dengan penelitian Widiyanti dimana mayoritas penderita HIV/AIDS berusia 20-29 tahun (18).

Dalam penelitian ini, mayoritas subjek penelitian telah menjalani terapi ARV paling lama 60 bulan dan memiliki Indeks Massa Tubuh diatas 18,5. Penelitian di Nigeria, terapi ARV dengan tingkat kepatuhan $\geq 95 \%$ berpengaruh terhadap peningkatan Indeks Massa Tubuh, jumlah CD4+, dan menekan jumlah virus dalam darah ODHA (20). Studi kohort pada wanita terinfeksi HIV yang menjalani terapi ARV dengan kepatuhan baik selama 10 tahun menunjukkan tidak ada risiko pengobatan ARV dalam waktu lama terhadap kejadian kelebihan berat badan dan obesitas (21).

Mayoritas subjek penelitian menderita anemia yaitu sebanyak 73,4\% memiliki kadar $\mathrm{Hb}$ dibawah $13 \mathrm{~g} / \mathrm{dL}$. Menurut penelitian Masaisa et al., faktor risiko penyebab anemia pada penderita HIV/AIDS adalah Indeks Massa Tubuh rendah, efek samping ARV yaitu Zidovudin, terapi ARV dengan kepatuhan rendah, kondisi imunologis rendah dengan jumlah $\mathrm{CD}^{+}$dibawah 200sel/ul, dan adanya infeksi oportunistik (22).

Hasil analisis statistik Fisher's Exact Test dan Odds Ratio, menunjukkan ada hubungan bermakna antara Indeks Massa Tubuh dengan jumlah $\mathrm{CD}^{+}$. Subjek penelitian dengan Indeks Massa Tubuh $\leq 18,5$ berisiko 13,867 kali untuk memiliki jumlah $\mathrm{CD}^{+} \leq 200$ sel/ul dibandingkan subjek dengan Indeks Massa Tubuh diatas 18,5. Kondisi malnutrisi cenderung mempercepat status HIV berkembang menjadi AIDS. Menurut WHO, jumlah $\mathrm{CD}^{+} \leq 200 \mathrm{sel} / \mathrm{ul}$ adalah kondisi klinis pasien HIV stadium 4 dimana progresivitas HIV telah parah menjadi AIDS. Hal ini didukung oleh penelitian Sharma et al., mortalitas tertinggi AIDS terjadi pada subjek dengan Indeks Massa Tubuh $<18,5$ dimana terjadi 2 kali lebih berisiko terjadi kematian karena AIDS pada awal tahun kedua terapi ARV (23). Penelitian Sumantri menunjukkan peluang kematian penderita HIV/AIDS semakin besar karena gabungan faktor risiko antara derajat anemia sedang sampai berat, IMT rendah $<18,5$, dan jumlah $\mathrm{CD}^{+} \leq 50$ sel/ul (24). Risiko untuk menjadi AIDS dan anemia meningkat pada pasien HIV dengan jumlah $\mathrm{CD}^{+}<200 \mathrm{sel} / \mathrm{ul}$ dan pengobatan Zidovudin (25).

Kondisi malnutrisi atau IMT rendah menyebabkan gangguan aktivasi dan proliferasi sel T-Limfosit, ekspresi sitokin, dan pengaturan adipokin. Asupan energi dan protein yang rendah menyebabkan berkurangnya ketersediaan glukosa sebagai sumber energi metabolisme sel T-Limfosit. Hal ini menghambat proliferasi sel TLimfosit. Akibatnya jumlah sel T-Limfosit turun. CD4 ${ }^{+}$ adalah molekul reseptor yang terletak di permukaan sel TLimfosit. Ketika jumlah sel T-Limfosit turun maka jumlah $\mathrm{CD}^{+}$juga turun. Sitokin merupakan glikoprotein yang memodulasi aktifitas differensiasi sel T-Limfosit. Kondisi malnutrisi menyebabkan menurunnya produksi sitokin, sehingga proses differensiasi sel T-Limfosit terganggu. Gangguan pada differensiasi sel T-Limfosit membuat tubuh rentan infeksi penyakit karena sistem imunitas tidak berjalan normal. Adipokin merupakan hormon yang disekresikan oleh sel adiposa. Salah satu adipokin adalah leptin. Leptin berperan sebagai regulator dalam metabolisme glukosa oleh sel T-Limfosit. Kurangnya asupan lemak pada malnutrisi menyebabkan jumlah sel adiposa sedikit dan berakibat produksi leptin menurun. Penurunan atau ketidakcukupan leptin menyebabkan proliferasi sel T-Limfosit terganggu yang akhirnya menyebabkan jumlah sel T-Limfosit turun (26-28). Peningkatan Indeks Massa Tubuh berhubungan dengan peningkatan jumlah $\mathrm{CD}^{+}$, menurunkan mortalitas dan progresivitas HIV menjadi AIDS (29). Malnutrisi pada awal mulai terapi ARV dan penurunan status gizi di awal 3 bulan terapi ARV dapat menjadi faktor tunggal penyebab terjadinya mortalitas sehingga diperlukan studi intervensi pemberian nutrisi selama terapi ARV (30).

Intervensi terhadap status gizi pasien HIV/AIDS dapat mendukung keberhasilan terapi ARV dengan kepatuhan tinggi. Intervensi dapat dilakukan dengan pemberian suplemen makanan dengan tujuan untuk meningkatkan fungsi imun selama menjalani terapi ARV. Pemberian suplemen mikronutrien berupa multivitamin dan Selenium selama 24 bulan pada pasien naif HIV yang menjalani terapi ARV dapat menunda progresivitas HIV menjadi AIDS dan aman bagi pasien (31). Pemberian asupan protein dan makanan sumber energi meningkatkan berat badan dan massa lemak, sedangkan olahraga teratur dengan dan tanpa aerobik dapat meningkatkan ketahanan insulin dan peningkatan massa tubuh. Senam aerobik dapat meningkatkan kebugaran fisik, fleksibilitas serta daya tahan jantung dan paru (32). Pemberian nutrisi dan olahraga teratur mengubah komposisi tubuh secara signifikan sehingga dapat diterapkan sebagai bentuk intervensi dalam mendukung terapi ARV dengan kepatuhan tinggi (33). Pemberian suplemen vitamin B12 dan asam folat bermanfaat meningkatkan status hematologis pasien yang mengalami gangguan fungsi sel darah merah karena efek penggunaan ARV dengan kepatuhan tinggi dalam waktu lama (34). Pemberian makanan tambahan pada pasien HIV dengan kondisi kurang nutrisi pada permulaan terapi ARV dapat membantu meningkatkan efek kepatuhan dalam pengobatan (35).

Tidak ada hubungan signifikan antara kadar $\mathrm{Hb}$ dengan jumlah $\mathrm{CD}^{+}$pada subjek penelitian ini. Kadar $\mathrm{Hb}$ subjek penelitian rendah dapat disebabkan oleh efek samping regimen obat ARV. Hal ini didukung penelitian Hidayati dkk menunjukkan bahwa Zidovudin dapat menyebabkan anemia. Zidovudin dapat menghambat sintesis DNA yang berperan dalam pembentukan heme dan globin pada proses pembentukan darah (36).

Jenis kelamin dengan $\mathrm{CD} 4^{+}$pada subjek penelitian ini tidak berhubungan signifikan. Hal ini berbeda dengan penelitian Maskew dimana pasien laki-laki memiliki peningkatan jumlah $\mathrm{CD}^{+}$lebih sedikit dibandingkan perempuan setelah menjalani terapi ARV (37). Hasil penelitian Akinbami menunjukkan jumlah $\mathrm{CD}^{+}$pasien perempuan relatif lebih tinggi dibandingkan laki-laki (38). Pasien lakilaki dengan hasil diagnosis positip HIV diawal pengobatan ARV cenderung memiliki jumlah $\mathrm{CD}^{+}$rendah dan jumlah virus lebih tinggi dibandingkan pasien perempuan (39).

Tidak ada hubungan bermakna antara umur dengan CD4 ${ }^{+}$ pada subjek penelitian ini. Berdasarkan penelitian Bhattar et al, peningkatan jumlah $\mathrm{CD}^{+}$pada pasien terapi ARV berusia $\geq 45$ tahun lebih rendah dibandingkan pasien berusia $<45$ tahun (40). Tidak ada hubungan bermakna antara lama terapi terhadap jumlah $\mathrm{CD}^{+}$subjek penelitian. Penelitian Wright et al., menunjukkan lama terapi dan pertambahan usia tidak menurunkan jumlah 
$\mathrm{CD}^{+}$pasien yang telah menjalani terapi ARV jangka panjang karena perbaikan imunitas yang diperoleh di 5 tahun awal terapi ARV tetap bertahan selama terapi ARV jangka waktu lama (41).

Indeks Massa Tubuh kurus (malnutrisi) berhubungan dengan jumlah $\mathrm{CD}^{+}$rendah yaitu $\leq 200$ sel/ul. Jumlah $\mathrm{CD}^{+}$dibawah 200 berkecenderungan untuk mempercepat perkembangan status HIV menuju stadium

\section{DAFTAR PUSTAKA}

1. Jiang $\mathrm{H}$, Xie $\mathrm{N}$, Cao $\mathrm{B}$, et al. Determinants of Progression to AIDS and Death Following HIV Diagnosis: A Retrospective Cohort Study in Wuhan, China. PloS ONE. 2013; 8(12): 1-11.

2. Direktorat Jenderal Pencegahan dan Pengendalian Penyakit. Laporan Situasi Perkembangan HIV-AIDS dan PIMS di Indonesia Januari-Maret 2017. Jakarta: Kementerian Kesehatan RI; 2017.

3. Langebeek N, Gisolf EH, Reiss P, et al. Predictors and Correlates of Adherence to Combination Antiretroviral Therapy (ART) for Chronic HIV Infection: A Meta-Analysis. BioMed Central Medicine. 2014; 12: 142-155.

4. Mbuagbaw J, Jingi AM, Noubiap JJN, et al. Patterns and Trends in Mortality among HIV-Infected and HIV-Uninfected Patients in a Major Internal Medicine Unit in Yaounde, Cameroon: A Retrospective Cohort Study. Journal of the Royal Society of Medicine Open. 2016; 7(9): 1-9.

5. Fanales-Belasio E, Raimondo M, Suligoi B, and Butto S. HIV Virology and Pathogenetic Mechanisms of Infection: A Brief Overview. Annali dell'Istituto Superiore di Sanità. 2010;46(1): 5-14.

6. Kementerian Kesehatan Republik Indonesia. Pedoman Nasional Tatalaksana Klinis Infeksi HIV dan Terapi Antiretroviral. Jakarta: Kementerian Kesehatan RI; 2011.

7. Rawat R, Mccoy SI, and Kadiyala S. Poor Diet Quality is Associated with Low CD4 Count and Anemia and Predicts Mortality among Antiretroviral TherapyNaive HIV-Positive Adults in Uganda. Journal of Acquired Immune Deficiency Syndrome. 2013; 62(2): 246-253.

8. Argemi X, Dara S, You S, et al. Impact of Malnutrition and Social Determinants on Survival of HIV-Infected Adults Starting Antiretroviral Therapy in ResourceLimited Settings. AIDS. 2012; 26(9): 1161-1166.

9. Duggal S, Chugh TD, and Duggal AK. HIV and Malnutrition: Effects on Immune System. Clinical and Developmental Immunology. 2012; 2012; 1-8.

10. Hu W, Jiang $\mathrm{H}$, Chen $\mathrm{W}$, et al. Malnutrition in Hospitalized People Living with HIV/AIDS: Evidence from a Cross-Sectional Study from Chengdu, China. Asia Pacific Journal of Clinical Nutrition. 2011; 20 (4): 544-550.

11. World Health Organization. Global Database on B o d y Mass l ndex. (O n I i n e ). http://apps.who.int/bmi/index. [diakses tanggal 8 Agustus 2017].
4 atau sakit berat yang mengarah kepada AIDS. Informasi ini masih merupakan hasil penelitian berdasarkan data yang diambil sewaktu. Perlu dilakukan studi kohort hubungan variabel status gizi dengan parameter imunologis, virologis, dan klinis dari ODHA. Dengan Demikian informasi yang diperoleh dapat lebih komprehensif untuk masukan dalam evaluasi program terapi antiretroviral.

12. Cappelini MD and Motta I. Anemia in Clinical Practice-Definition and Classification: Does Hemoglobin Change with Aging? Seminars in Hematology. 2015; 52(4): 261-269.

13. Unit Pelaksana Teknis AIDS Tuberkulosis Malaria. Laporan Kasus HIV/AIDS Provinsi Papua Triwulan IV (per 31 Desember) 2016. Papua: Dinas Kesehatan Provinsi Papua; 2016.

14. Ubra RR. Faktor-Faktor yang berhubungan dengan Kepatuhan Pengobatan Minum ARV pada Pasien HIV di Kabupaten Mimika-Provinsi Papua 2012. [Tesis]. Universitas Indonesia, Jakarta. 2012.

15. Widiyanti M. Pemetaan Subtipe, Analisis Filogenetik dan Deteksi Mutasi Fragmen Pengkode DNA Reverse Transcriptase dan Protease Human Immunodeficiency Virus-1 (HIV-1) dari Orang dengan HIV/AIDS (ODHA) yang telah Diobati dengan Antiretroviral di Kabupaten Mimika Provinsi Papua. Papua: Balai Litbang Biomedis Papua; 2015.

16. Jamil KF. Profil Kadar CD4 terhadap Infeksi Oportunistik pada Penderita Human I mmunodeficiency Virus/Acquired Immunodeficiency Syndrome (HIV/AIDS) di RSUD dr. Zainoel Abidin Banda Aceh. Jurnal Kedokteran Syiah Kuala. 2014; 14(2): 76-80.

17. Saktina PU dan Satriyasa BK. Karakteristik Penderita AIDS dan Infeksi Oportunistik di Rumah Sakit Umum Pusat Sanglah Denpasar Periode Juli 2013 sampai Juni 2014. E-Jurnal Medika. 2017; 6(3): 1-6.

18. Widiyanti M, Sandy S, dan Wibowo HA. Analisis Subtipe HIV-1 dan Faktor Penyebarannya pada Penderita HIV di RS. Yowari Kabupaten Jayapura, Papua. Jurnal Biologi Papua. 2014; 6(1): 25-30.

19. UNAIDS. Global AIDS Update 2016. (Online) 2016. http://www.unaids.org/sites/default/files/media_a sset/global-AIDS-update-2016_en.pdf

20. Olowookere SA, Fatiregun AA, Ladipo MMA, AbioyeKuteyi EA, and Adewole IF. Effects of Adherence to Antiretroviral Therapy on Body Mass Index, Immunological and Virological Status of Nigerians Living with HIV/AIDS. Alexandria Journal of Medicine. 2016; 52(1): 51-54.

21. Sharma A, Bynum SA, Schneider MF, et al. Changes in Body Mass Index following HAART Initiation among HIV-Infected Women in the Women's Interagency HIV study. Journal of AIDS and Clinical Research. 2015; 5: 1-19.

22. Masaisa F, Gahutu JB, Mukiibi J, Delanghe J, and Philippe J. Anemia in Human Immunodeficiency Virus-Infected and Uninfected Women in Rwanda. The American Journal of Tropical Medicine and 
Hygiene. 2011; 84(3): 456-460.

23. Sharma A, Hoover DR, Shi Q, et al. Relationship between Body Mass Index and Mortality in HIVInfected HAART Users in the Women's Interagency HIV Study. PloS ONE. 2015; 10(12): 1-16.

24. Sumantri $R$, Supandiman I, Indjradinata $P$, van der Ven A, and van Crevel R. Peluang Kematian Penderita Human Immunodeficiency Virus-Acquired Immune Deficiency Syndrome berdasarkan Gabungan Derajat Anemia, Indeks Massa Tubuh, dan Jumlah Cluster Differentiation 4. Majalah Kedokteran Bandung. 2012; 44(1): 50-56.

25. Santos AC and Almeida AM. Nutritional Status and CD4 Cell Counts in Patients with HIV/AIDS receiving Antiretroviral Therapy. Revista da Sociedade Brasileira de Medicina Tropical. 2013; 46(6): 698703.

26. Koethe JR, Heimburger DC, Praygod G, and Filteau S. From Wasting to Obesity: The Contribution on Nutritional Status to Immune Activation in HIV Infection. The Journal of Infectious Diseases. 2016; 214 (S2): S75-S82.

27. Gerriets VA and Maclver NJ. Role of T Cells in Malnutrition and Obesity. Frontiers in Immunology. 2014; 5(8): 379-389.

28. Torres CG, Martinez HG, Miliar A, et al. Effect of Malnutrition on the Expression of Cytokines Involved in Th1 Cell Differentiation. Nutrients. 2013; 5(2): 579-593.

29. Miftahurachman dan Wisaksana R. Hubungan antara Indeks Massa Tubuh dan Jumlah CD4 pada Penderita HIV yang Mendapat Pengobatan ARV. Majalah Kedokteran Bandung. 2015; 47(4): 237-241.

30. Liu E, Spiegelman D, Semu H, et al. Nutritional Status and Mortality among HIV Infected Patients receiving Antiretroviral Therapy in Tanzania. The Journal of Infectious Diseases. 2011; 204(2): 282-290.

31. Baum MK, Campa A, Lai S, et al. Effect of Micronutrient Supplementation on Disease Progression in Asymtomatic, Antiretroviral-Naive, HIV-Infected Adults in Botswana: A Randomized Clinical Trial. The Journal of the American Medical Association. 2013; 310(20): 2154-2163.

32. Candrawati S, Sulistyoningrum E, Prakoso DBA, and Pranasari N. Senam Aerobik Meningkatkan Daya
Tahan Jantung Paru dan Fleksibilitas. Jurnal Kedokteran Brawijaya. 2016; 29(1): 69-73.

33. Leyes P, Martinez E, and Forga MT. Use of Diet, Nutritional Supplements and Exercise in HIV-Infected Patients Receiving Combination Antiretroviral Therapies: A Systematic Review. Antiviral Therapy. 2008; 13(2): 149-159.

34. Rezaei E, Ebrahim-Saraie HS, Heidari H, et al. Impact of Vitamin Supplements on HAART Related Hematological Abnormalities in HIV-Infected Patients. Medical Journal of the Islamic Republic of Iran. 2016; 30(1): 1-6.

35. Cantrell RA, Sinkala M, Megazinni K, et al. A Pilot Study of Food Supplementation to Improve Adherence to Antiretroviral Therapy among Food Insecure Adults in Lusaka, Zambia. Journal of Acquired Immune Deficiency Syndromes. 2008; 49(2): 190-195.

36. Hidayati NR, Abdillah S, dan Keban SA. Analisis Adverse Drug Reactions Obat Anti Retroviral pada Pengobatan Pasien HIV/AIDS di RSUD Gunung Jati Cirebon Tahun 2013. Pharmaciana. 2016; 6(1): 79-88.

37. Maskew M, Brennan AT, Westreich D, McNamara L, MacPhail AP, and Fox MP. Gender Differences in Mortality and CD4 Count Response among Virally Suppressed HIV-Positive Patients. Journal of Women's Health. 2013; 22(2): 113-120.

38. Akinbami A, Dosunmu A, Adediran A, et al. CD4 Count Pattern and Demographic Distribution of TreatmentNaive HIV Patients in Lagos, Nigeria. AIDS Research and Treatment. 2012; 2012: 1-6.

39. Kumar M, Kumar R, Mahdi AA, and Dhole TN. Study of Viral Load and CD4 Count in Diagnosis of HIV-1 Positive Patients. Journal Family Medicine. 2017; 4(4): 1117-1119.

40. Bhattar S, Mehra B, Bhalla P, and Rawat D. A Study on the Effect of Age, Sex and Baseline CD4 T-lymphocyte Count on CD4 Cell Count Recovery in HIV Positive Patients Receiving HAART. The Journal of Communicable Diseases. 2015; 47(1): 5-7.

41. Wright ST, Petoumenos K, Body M, et al. Ageing \& Long-Term CD4 Cell Count Trends in HIV-Positive Patients with 5 Years or more Combination Antiretroviral Therapy Experience. HIV Medicine. 2013; 14(4): 208-216. 